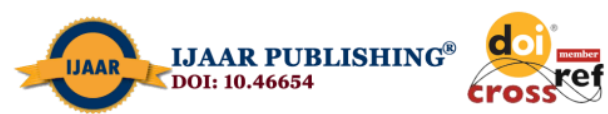

International Journal of Advanced Academic Research (Social and Management Sciences) | ISSN: 2488-9849

Journal DOI: 10.46654/ij.24889849

Vol. 6, Issue 10 (October, 2020) | www.ijaar.org

Article DOI: 10.46654/ij.24889849.s61030

\title{
EMPIRICAL INVESTIGATION OF TAX COMPLIANCE DETERMINANTS IN KATSINA STATE, NIGERIA
}

\author{
Sani Rabiu \\ And \\ Daud Mustafa, $P h D$ \\ Department of Economics and Development Studies \\ Federal University Dutsin-Ma (FUDMA), Katsina State - Nigeria. \\ mdaud@fudutsinma.edu.ng \& $\underline{\text { mdaud1431h@gmail.com }}$ \\ Corresponding Author's Email: sanirabiu555@gmail.com
}

\begin{abstract}
Tax compliance is determined by many factors, which are categorized into social, economic, institutional, demographic and individual factors. In this regard, the main objective of this study is to empirically evaluate and understand tax compliance determinants usingdata generated from agro-allied industries in some selected local government areas of Katsina state, Nigeria. As such, primary source of data was employed through the use of structured questionnaire to collect relevant information from all the 133 agro-allied industries in the study area and multinomial probit model was adopted for estimation. Basically, the findings from this study indicate that tax rate, level of income, perception on government spending, change in government policy, simplicity of tax system and efficiency of the tax authority are significant determinants of tax compliance among agro-allied industries in the study area; whereas perception on equity and peer influence are insignificant determinants. In this connection therefore, the study recommends that government should ensure efficient allocation of public funds, in order to fiscally motivate taxpayers to develop compliance attitude. Also, policy formulation and implementation should physically be centered towards improving the quality of life of citizens, so as to improve taxpayers' belief in policy makers thereby increasing the level of compliance. And finally, the tax authorities should be transparent and accountable in tax collection, which may result to positive compliance as well as increase in tax revenue yield for national development.
\end{abstract}

Keywords: Tax compliance determinants; Agro-allied industries; Probit model; Tax revenue; Nigeria 


\section{Introduction}

It has been asserted that one of the major ways for attaining economic growth and development is through the provision of developmental goods and services. However, this cannot be achieved without reliable sources of revenue (Okafor, 2012). Thus, one of the reasonable sources of revenue generation is tax (Azubike, 2009). As such, tax revenue plays a significant role in the development of modern society (Aladejebi, 2018). Governments of the United States, the United Kingdom, France, Germany, South Africa and Ghana, among others depend largely on tax income to finance various projects in their countries. In this regard therefore, tax is a compulsory levy imposed by government on the capital and/or income of individuals and companies, which serves as a source of revenue for the performance of various legitimate functions of the state (Olaoye, Ashaolu \& Adewoye, 2009). According to Ojo (2003), tax is one of the tools used by governments at all levels (federal, state and local) to achieve political, social and economic advancement. Therefore, Nigerian economy as a major player in the African continent and one of the emerging economies of the world, can achieve growth and development through efficient tax administration. Despite the significant role of tax in achieving macroeconomic objectives, most of the sub-Saharan African (SSA) countries do not utilize this great opportunity in which Nigeria is a major victim (Akintoye \& Dada, 2013). This may be as a result of over reliance on other sources like crude oil, and/or challenges surrounding the tax system such as complexity of tax payment and collection, corruption and non-compliance by taxpayers, among others.

However, the amount of tax to be generated is determined by the level of compliance by the taxpayers. In this regard therefore, Franzoni (1999) sees compliance to tax laws as a true reporting of the taxable income, appropriate computation of the tax payable, filing of the returns and timely payment of tax liabilities. According to Kirchler (2007), non-compliance may occur due to the complete failure of filing tax return, underestimation of income and overstatement of expenses with a deliberate intention of cutting tax burden. Oyedele (2016) describe tax compliance behavior in Nigeria as poor. Most of the citizens fail to comply positively as a result of lack of confidence in government (Ola, 2001). Others comply positively only for the fair of being audited or the penalty that may come in place after tax audit (Anyaduba, Eragbhe \& Kennedy, 2012; Ladi \& Henry, 2015).Admittedly, the current administration of President Muhammad Buhari (PMB) aims at paying considerable attention on other multiple sources of revenue, such as corporate income tax as spelt out in the Economic Recovery and Growth Plan for 2017-2020 (ERGP, 2017). No doubt that one of the most reliable sector that can provide government with tax revenue in this regard is the agroallied industry. Because, in trying to address the problem of food insecurity and create employment opportunities, the federal government opens room for local and foreign investors to massively invest in agro-allied industry. Moreover, as a result of covid-19 pandemic most industries were locked and borders were closed, so as to curtail the widespread of the disease, but the agro-allied industry is not affected by the lockdown. This is in view of the fact that farms and production, sales and distribution of food items are among the businesses and services that are exempted. Therefore, if agro-allied industries comply with the tax law, it will help government immensely in maximizing revenue generation for development.

It is important to state that tax compliance determinants imply tax influencing factors (Palil, 2010) and they have been classified differently by different scholars and writers. Studies in this regard by Fischer et al. (1992), Kirchler (2007), Loo (2006), Allingham and Sandmo 
(1972) and Jackson and Milliron (1986), among others, identify factors such age, gender, education level, occupation, tax knowledge, awareness of offence, personal financial constraint, perception on equity, change in government policy, peer influence, tax rate, income level, tax audit, perception on government spending, efficiency of tax authority and simplicity of tax system, among others, as the determinants of tax compliance behavior. The above mentioned and many other authors overlap these classifications on one another and thus, they categorized them into five (5): demographic, individual, social, economic and institutional factors. Admittedly, this study focuses only on economic, social and institutional factors as determinants because the study is concerned about corporate organizations. Therefore, the main objective of this study is to investigate the factors that determine tax compliance with evidence from agro-allied industries in Katsina state, Nigeria. Nevertheless, the specific objectives to be achieved are: (i.) to evaluate the effect of economic factors on tax compliance in agro-allied industries of Katsina state; (ii.) to investigate the effect of social factors on tax compliance in agro-allied industries of Katsina state; and (iii.) to examine the effect of institutional factors on tax compliance in agro-allied industries of Katsina state.

\section{Literature Review}

\subsection{Conceptual Background}

\subsubsection{Tax Compliance}

Tax compliance is the extent to which a citizen complies (or fails to comply) with the tax laws of the state. For example, filing return, reporting income, and appropriately and conveniently making the tax payment. Tax compliance refers to the willingness to obey all tax rules and regulations as outlined by law without the use of force by the state (Ojochogwu $\&$ Stephen, 2012). Also, tax compliance means reporting tax return, correctly declaring gains and deductions and paying levied taxes in a timely manner. According to Franzoni (1999), compliance to tax laws typically means the actual reporting of income,filing of tax returns, correct assessment of the tax payable, and paying the tax liabilities by the due date. Furthermore, Deyganto (2018) notes that the level of trust in government has a significant influence on the level of tax compliance. Level of transparency is another factor affecting tax compliance, the higher the level of confidence in government spending, the greater the level of compliance and vice-versa (Fagbemi \& Abogun, 2015). Abiola and Asiweh (2012) submitted that the level of taxpayers' compliance is greatly influenced by the way government spends public funds, extent to which corruption and fraud surround government officials and willingness of government to fight corruption and fraud. Perception of taxpayers on accountability of government, nature of tax laws and administration and awareness of tax collection procedures by citizens, influence the level of compliance among taxpayers in any country (Fagbemi et al., 2010).

\subsubsection{Tax Non-Compliance}

According to James and Alley (2002), tax non-compliance is a situation in which a taxpayer deliberately or accidentally fails to fulfill the tax obligation of his/her country. Roth, Scholz and Dryden-Witte (1989) noted that tax non-compliance refers to the failure to file return, declare income or report allowable deductions from taxable income, such as tax credit, adjustments, exemptions, deductions and a host of others. Furthermore, Soos (1991) argued that non-compliance can be broadly categorized into four: failure of filling tax return; declaring less income, gain or profit; stating high tax claims such as expenses, exemptions and deductions; and failing to freely and completely pay the tax due in a timely manner. Noncompliance may take different forms, which may deliberately undermine the country's tax 
laws for the satisfaction of personal interest (tax evasion and tax avoidance) or unintentional, which may be as a result of unawareness, oversight, errors or mistakes in applying tax laws (Alabede, Ariffin \& Idris, 2011).

\subsubsection{Tax Evasion}

Tax evasion is the illegal non-payment or underpayment of tax. It involves the act of following serious ways and illegal means in order to reduce the tax burden or not pay the tax at all (Soyode and Kayola, 2006). According to Akinyomi and Okpola (2013), tax evasion exists when private individuals and corporate bodies illegally attempt to reduce or fail to pay tax liabilities. It is an intentional act of not declaring all taxable income in order to pay lesser tax (Alm \& Martinez-Vazquez, 2001), which is totally illegal by the law of the state. It entails an intentional attempt by the taxpayer to cover-up and misstate the level of taxable gain or income to the government, so as to reduce the amount of tax payment. It includes false tax reporting, such as stating less income, than amount actually earned, or overstating exemptions and/or deductions. Kabel and Kwokah (2009) postulated that tax evasion entails fraudulent, false and intentional hiding of figures and facts, in order to reduce tax liabilities or avoid tax payable.

\subsubsection{Tax Avoidance}

Tax avoidance is the legal use of tax laws to reduce one's tax burden. It involves taking advantage of tax laws of the state to hide from civic obligations. Kabel and Kwokah (2009) posited that tax avoidance is used to mean several deceitful acts use by taxpayers to take advantage of tax laws of a country with deliberate intension of saving tax, so as to hide from a greater liability that will reduce the amount of their earnings. Therefore, tax avoidance can be found among all classes of taxpayers by hiding under a certain law of the state without physically breaking it. In the process of avoiding tax, a taxpayer may bend an existing tax law to cut tax liabilities that the government never intended (HM Treasury, Revenue \& Custom, 2019).

\subsubsection{Determinants of Tax Compliance}

\subsubsection{Economic Factors}

Economic factors in relation to tax compliance refer to the steps taken to measure the costs and benefits in relation to tax collection (Loo, 2006). According to Alm (1995), taxpayers are logical economic evaders who try to measure the costs and/or benefit of evading tax. This factor is another major category among the determinants of tax compliance as stated above. It includes sub-factors like tax rate, income level and perception on government spending (Deyganto, 2018). Also, Whitte and Woodbury (1985) noted that a higher marginal tax rate may likely result to a rapid increase in tax evasion. Tanzi (1980) observes that it has negative correlation with tax compliance i.e. the higher the tax rate the lower the compliance, which is consistent with the position of Laffer curve concept. Furthermore, perception on government spending affects compliance attitude as well. According to James and Alley (2002), tax is among the means through which wealth is transferred from private sector to the government. People of each and every country put eyes on the kind of goods and services their governments spend their wealth on. If a nation spends efficiently and effectively, it will encourage taxpayers to comply with tax laws. Contrary to this, if citizens do not see the impact of government spending it may likely cause a serious tax evasion (Deyganto, 2008). According to Sparc Report (2014), various tax authorities in Nigeria have been coming-up with various policy measures to encourage positive compliance among taxpayers. However, 
addressing the issue of tax compliance requires a clear understanding of factors that are fundamental to the individual taxpayers in making decision of whether to comply positively or negatively.

\subsubsection{Social Factors}

According to Togler (2007) and Kirchler (2007), tax influencing factors from the social perspective refer to willingness of taxpayers to comply with tax laws based on norms and value of their society. In this regard, taxpayers allow other people's behavior and their social environment to determine their compliance behavior. It comprises: perception on equity and fairness, change in government policy and peer group influence. According to Israel (1992), taxpayers' perception on fairness of the tax system influences their tax compliance behavior. Another research by Hasseldine and Hite (2003) suggested that change in government policy regarding social condition and economic policy is an important factor that influences tax compliance behavior. Furthermore, Ajzen and Fishbein (1980) are of the view that peer group influence plays a significant role in determining compliance behavior of citizens.

\subsubsection{Institutional Factors}

It refers to the relationship that exists between government/tax authorities and taxpayers regarding tax collection and payment procedure (Richardson, 2008). The institutional factors contain sub-factors like efficiency of tax authority, probability of being audited, and simplicity of the tax system (Mohani, 2001). Both government and the tax authority must efficiently work hand in hand to reduce the level of tax evasion (Dubbin, 2004). A research conducted by Richardson (2008) suggested that government plays a vital role in determining the compliance behavior of her citizens. Amina and Saniya (2015) concluded that one of the factors that encourage the compliance behavior of taxpayers is when the government designs a simple tax system. Making tax return simple by the tax authority encourages taxpayer to comply and it is a strong tool than employing additional tax agents (Silvani \& Baer, 1997). However, corruption leads to a serious tax evasion, which results to negative effect on tax collection, especially in developing countries (Ajaz \& Ahmad, 2010). A wide spread corruption at all levels (federal, state and local) of government used to serve as reason of evading tax and thus, plays an important role in accounting for lower amount of tax revenues (Okpe, 2000). According to him, this will go a long way in bringing about a revenue gap in Nigeria. Thus, tax officials may be in a position to cooperate secretly and illegally with taxpayers to collect bribes (Martini, 2014). According to Transparency International (2013), there is prevalence of bribe extortions among tax officials particularly in some African countries and Nigeria is one of them.

\subsubsection{Conceptual Model of Tax Compliance Determinants}

The variable at the left hand side of figure 1 (tax compliance) is the dependent variable while the three (3) variables on the right hand side (social, economic and institutional factors) are the independent variables. 


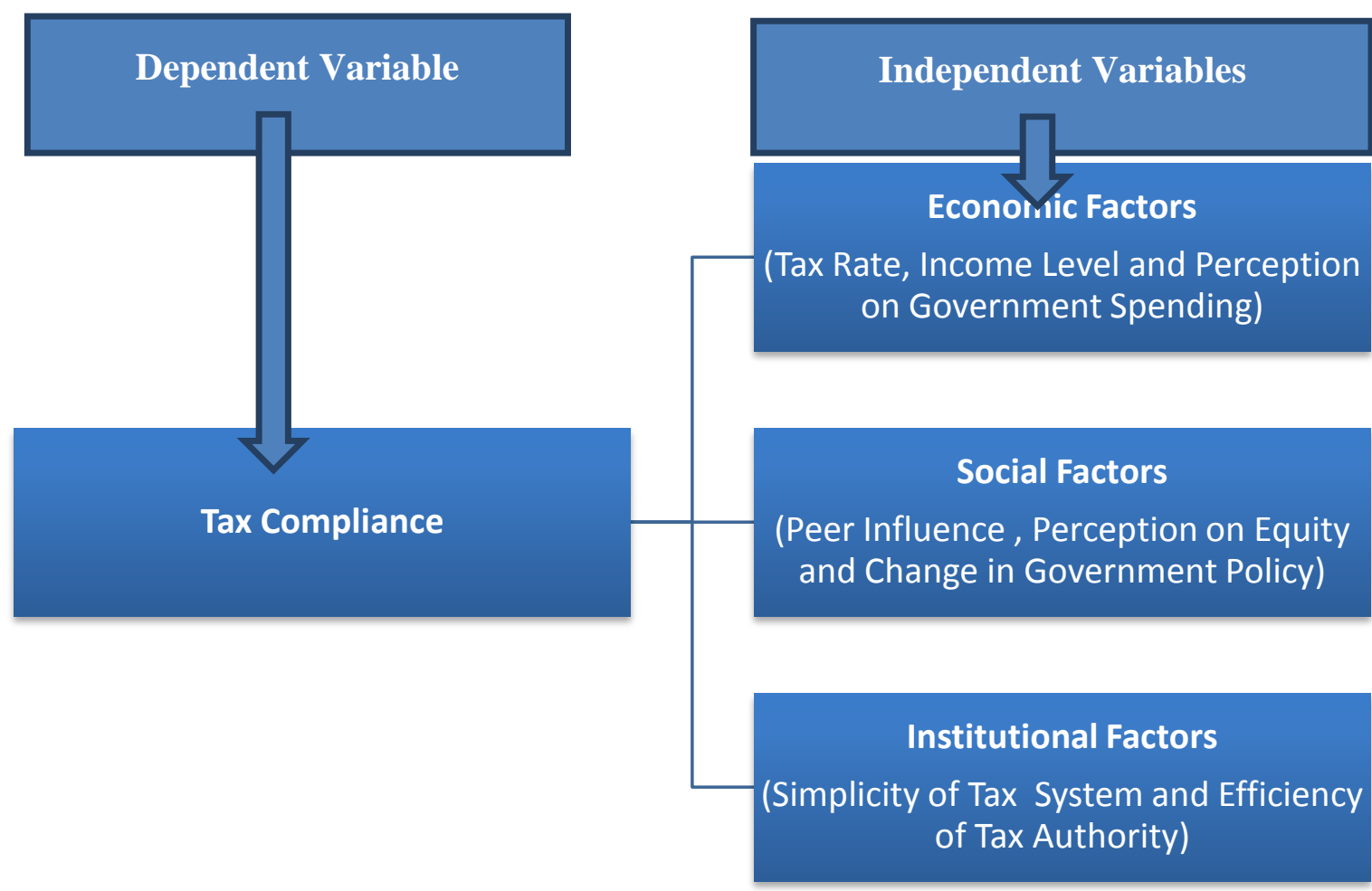

Figure 1: Conceptual Model of Tax Compliance Determinants

Source: Constructed by the Authors (2020).

\subsection{Theoretical Framework}

\subsubsection{Benefit Theory of Taxation}

This theory is based on the fact that the policy makers should levy tax according to the benefits conferred on them. The larger the benefit a citizen receives from government, the larger the amount of tax he should pay and vice-versa. Taxpayers should pay tax in proportion to the benefits they enjoyed (Almetal., 1992). Alm and Martinez-Vazguez (2001) suggested each and every citizen should first benefit from the goods and services provided by government before he/she pays tax. Therefore, if individual " $\mathrm{A}$ " benefits more from government expenditure than individual "B", a high amount of tax should be levied on the former than the latter. As such, this theory reflects the concepts of vertical and horizontal equity, which considers both revenue and expenditure. However, the major obstacle of this 
theory is that, estimation of the benefits enjoyed by each taxpayer from government expenditure is not to be captured; therefore, a proper application of benefit theory becomes difficult (Neill, 1999). Similarly, if a low income earner benefits more from public expenditures than a high income earner it will not make sense to levy high tax on the former than the latter (Alm and Martinez-Vazguez, 2001). For instance, in some communities poor men depend largely on government expenditure like hospitals, schools, power and water supply and other social and economic goods and services, while rich men in the same society may use their financial resources to obtain many of such kind. In this connection, it is against the principle of equity and justice to levy high tax on poor people residing around these areas, even though they receive more benefit than rich.

\subsubsection{Fiscal Exchange Theory}

The fiscal exchange theory posits that an efficient provision of capital projects by a government motivates compliance behavior of citizens and that when a government competently increases the provision of developmental goods and services preferred by citizens, that will result to a corresponding increase in the level of compliance (Cowell \& Gordon, 1988; Levi, 1988; Tilly, 1992; Moore, 2004). Similarly, Alm et al. (1992) state that availability of public goods and services leads to increase in compliance attitude. The major concern of citizens is the goods and services they receive from government as a return for the tax they paid. In this connection, availability of public goods and services provided by government and taxation are translated as a contract between the government and taxpayers (Moore, 2004). Moreover, payment of taxes by citizens may be as a result of the fact that they value the government spending, and therefore, tax payment serves as their contribution in an attempt to assist government to finance the provision of developmental goods and services (Fjeldstad \& Semboja, 2001). According to Ali, Fjeldstad and Sjursen (2014), positive benefit from government expenditure may result to a corresponding increase in the probability of taxpayers' voluntary compliance without using enforcement tools.Despite the fact that most of the taxpayers cannot measure the exact value of the benefit they receive from government expenditure as a return for the tax payment; nonetheless, they have their own general impressions and attitudes concerning government spending (Richupan, 1987). It is therefore, reasonable to assume that a taxpayer's attitude is affected by the satisfaction or dissatisfaction with government expenditure. Thus, if the tax system is perceived by the taxpayers as unjust, then tax evasion may in some cases be considered as an attempt to compensate unjust spending of public fund. The fiscal exchange theory has received much consideration and it is theoretically well established (D'Arcy, 2011).

\subsubsection{Social Influence Model}

According to social influence model, taxpayers' compliance behavior towards the tax laws of the state is assumed to be affected by the attitude and social norms of his/her reference group (Snavely, 1990). It is therefore, assumed that an individual compliance behavior is much affected by his/her social interaction with his/her reference group such as neighbors, relatives and friends. As such, if a citizen is aware that many people in his/her group who are important to him/her evades taxes, then, his/her compliance behavior will be weaker (Ali, Fjeldstad and Sjursen, 2014). Similarly, a social relationship may help prevent the occurrence of tax evasion if the taxpayer fears the social sanction that is publicly imposed on another individual within the same reference group as a result of evading tax. A theoretical research by Banerjee (1992) indicates that compliance behavior may be affected by social influence, particularly by influencing the perceived probability of detection. However, empirical 
findings on taxpayer's compliance behavior in most of the Western countries revealed that those who were reported to have voluntarily complied believe that their friends and peers (taxpayers in general) comply, whereas those who were reported to have avoided tax believe that others avoid it (Yankelovich et al., 1984). Therefore, empirical evidence confirmed that perception about the taxpayers' honesty may affect compliance behavior of others.

\subsection{Empirical Review}

Oladele, Aribaba, Ahmodu, Yusuff and Alade (2019) in their study, "The effectiveness of tax enforcement tools as panacea for improving tax compliance and overall tax income in Ondo State, Nigeria"; utilized Ordinary Least Square to analyze their data. The evidence from the result showed that marginal increase in the probability of being audited and penalty after tax result to increase in tax audit compliance in Ondo State. Another study by Assfawa and Sebhat (2019) titled, "Analysis of tax compliance and its determinants: Evidence from Kaffa, Bench Maji and Sheka zones category B taxpayers, SNNPR, Ethiopia". The data was examined with the use of descriptive statistics and ordered logit model. The results showed that tax compliance was positively affected by taxpayers' level of education, taxpayers' awareness and their level of tax knowledge, simplicity of the tax system, taxpayers' attitude towards tax, perception of taxpayers on government expenditure, and rewarding scheme for loyalty among taxpayers. These findings are consistent with the findings of Riahi-Belkaoui (2004) and Richardson (2008). Again, Tilahun (2018) examined "The economic and social factors of voluntary tax compliance: Evidence from Bahirdar city". He employed ordered logit model to analyse the data. The results showed that factors such as tax rate, taxpayers' perceptions on government expenditure, efficiency of the tax system, penalty after tax audit and cost of compliance were found to be the factors determining taxpayers' voluntary compliance. Also, another study by Manaye (2018) titled, "The determinants of tax compliance in Wolaita Sodo and Tercha Town, Ethiopia", adopted multiple linear regression model as the methodology of the study. The findings revealed that tax compliance behavior was influenced by tax audit, personal financial constraints, and changes in government policy. As such, his findings are consistent with those of Jackson and Milliron (1986), RiahiBelkaoui (2004), Richardson (2008) and Deyganto (2008).

Furthermore, a study by Eluro (2018), "The determinants of tax compliance under the selfassessment scheme in Delta North Senatorial zone, Nigeria." Both descriptive and inferential statistics were utilized in the analysis. Result of the investigation shows that tax clearance certification is the most important determinant of tax compliance and that it is leastdetermined by social acceptance. Whereas, the complexity of filing process was ranked the highest among the causes of non-compliance. In addition, there is low tax-related government assistance with respect to compliance under the self-assessment scheme. Similarly, a study by Deyganto (2018) on the examination of the factors influencing taxpayers' voluntary compliance attitude with tax system: A case of Gedeo Zone of Southern Ethiopia. To achieve the research objectives, the researcher adopted mixed research approach, binary logistic regression in the form of probit and logit model. The result showed that out of fourteen explanatory variables contained in the model, seven variables such as age, probability of being audited, gender, lack of tax knowledge, perception on tax rate, awareness on penalty and simplicity of tax system were found to be major factors affecting taxpayers' voluntary compliance behavior in the study area. His findings are consistent with that of Warneryd and Walerud (1982).Also,Ojochogwu and Stephen (2012) investigated "The factors that affect tax compliance among Small and Medium Enterprises (SMEs) in North 
Central Nigeria". The study adopted logit model to analyze the response variable. The findings revealed that difficulties of filing procedure and high tax rates are the most significant factors resulting to non-compliance among SMEs. Other factors such as lack of tax knowledge and multiple taxations affect tax compliance among the SMEs only to a lesser degree. The results are consistent with those by Whitte and woodbury (1985), Park and Hyun (2003) and Tanzi (1980).

\section{Methodology}

Experimental research design was adopted in this study, in order to analyze the influence of social, economic and institutional factors on tax compliance. Data from agro-allied industries in Katsina state was collected. Therefore,since most of the agro-allied industries in Katsina state are located in Katsina South Senatorial Zone (Funtua Zone) then, the population of the study consists of all the 133 agro-allied industries located in the six (6) selected local governments of Katsina state (Funtua, Dandume, Faskari, Bakori, Malumfashi and Kankara local governments). Total population sampling, which is a type under purposive sampling technique is adopted in this study. This is because the population of the study is small and the elements of the population share common set of characteristics. Total population sampling is a type of purposive sampling technique where a researcher chooses to examine the entire population in which the population size is relatively small and share a common set of characteristics (Kothari, 2004). Importantly, primary data was collected through the use of self-administered questionnaires, which were distributed to the Chief Executive Officer (CEO)/ Managing Director of each company who filled it or assigned any officer to respond on behalf of the company.

Furthermore, this study is qualitative in nature in which the dependent variable entails the probability of four (4) outcomes, which include: tax compliance (1), tax evasion (2), tax avoidance(3) and other forms of tax non-compliance (careless errors and mistakes) (4). As such, the study developed the following functional model:

$\mathrm{TC}=\mathrm{f}(\mathrm{EF}, \mathrm{SF}, \mathrm{INF})$

Where TC is the tax compliance, EF is the economic factor, SF is the social factor and INF is the institutional factor. The above equation shows that tax compliance depends on the explanatory variables which are economic, social and institutional factors. Based on the above equation the following econometric model was formulated:

$Y_{i}=\beta_{0}+\beta_{1} x_{1}+\beta_{2} x_{2}+\beta_{3} x_{3}+e_{i}$

Where:

$x^{\prime} s$ are the column vector of explanatory variables, $\beta^{\prime} s$ are the column vector of parameters (coefficients) to be estimated, $\beta_{0}$ is the intercept and $e_{i}=$ stochastic error term which represent all the unobservable factors of tax compliance behavior. The multiple response variable $\quad \mathrm{Y}_{\mathrm{i}}$ is written as: $Y_{i}=1$ for tax compliance

$Y_{i}=2$ for tax evasion

$Y_{i}=3$ for tax avoidance

$Y_{i}=4$ for other forms of tax non-compliance.

Thus, the choice pattern of Multinomial probit model can take the following forms: 


$$
\begin{aligned}
& \mathrm{Y}_{\mathrm{i}}=\mathrm{X}_{\mathrm{TC}} \beta_{\mathrm{TC}}+e_{T C} \\
& \mathrm{Y}_{\mathrm{i}}=\mathrm{X}_{\mathrm{TE}} \beta_{\mathrm{TE}}+e_{T E} \\
& \mathrm{Y}_{\mathrm{i}}=\mathrm{X}_{\mathrm{TA}} \beta_{T A}+e_{T A} \\
& \mathrm{Y}_{\mathrm{i}}=\mathrm{X}_{\mathrm{TN}} \beta_{T N}+e_{T N}
\end{aligned}
$$

Where:

$\mathrm{TC}=$ Tax Compliance

$\mathrm{TE}=$ Tax Evasion

$\mathrm{TA}=$ Tax Avoidance

$\mathrm{TN}=$ other forms of Tax Non-compliance

$e_{T C}, e_{T E}, e_{T A}$ and $e_{T N}$ are error terms or other factors affecting $\mathrm{Y}_{\mathrm{i}}$

However, if

$\mathrm{X}_{\mathrm{TC}} \beta_{T C}+e_{T C}>\max \left(X_{T E} \beta_{T E}+e_{T E}, X_{T A} \beta_{T A}+e_{T A}, X_{T N} \beta_{T N}+e_{T N}\right)$ then $\mathrm{Y}_{\mathrm{i}}=1 \ldots . \mathrm{III}$

$\mathrm{X}_{\mathrm{TE}} \beta_{T E}+e_{T E}>\max \left(X_{T C} \beta_{T C}+e_{T C}, X_{T A} \beta_{T A}+e_{T A}, X_{T N} \beta_{T N}+e_{T N}\right)$ then $\mathrm{Y}_{\mathrm{i}}=2 \ldots \ldots . . \mathrm{IV}$

$\mathrm{X}_{\mathrm{TA}} \beta_{T A}+e_{T A}>\max \left(X_{T C} \beta_{T C}+e_{T C}, X_{T E} \beta_{T E}+e_{T E}, X_{T N} \beta_{T N}+e_{T N}\right)$ then $\mathrm{Y}_{\mathrm{i}}=3 \ldots . \mathrm{V}$

$\mathrm{X}_{\mathrm{TN}} \beta_{T N}+e_{T N}>\max \left(X_{T C} \beta_{T C}+e_{T C}, X_{T E} \beta_{T E}+e_{T E}, X_{T A} \beta_{T A}+e_{T A}\right) \quad$ then $\mathrm{Y}_{\mathrm{i}}=4 \ldots \mathrm{VI}$

The above depict that when $Y_{i}=1$ the taxpayer has positive compliance, but when $Y_{i}=2$ the taxpayer evades the tax, for $Y_{i}=3$ he avoids tax and lastly when $Y_{i}=4$ the taxpayer has other forms of non-compliance.As a matter of fact, flowing from the objectives of this study in the introduction, the following hypotheses have been formulated for validation:

$\mathrm{H}_{01:}$ there is no impact of tax rate on tax compliance among agro-allied industries in Katsina state, Nigeria.

$\mathrm{H}_{02}$ : Income level does not affect tax compliance among agro-allied industries in Katsina state, Nigeria.

$\mathrm{H}_{03}$ : Perception on government spending does not influence tax compliance among agroallied industries in Katsina state, Nigeria.

$\mathrm{H}_{04}$ : Perception on equity has no significant effect on tax compliance among agro-allied industries in Katsina state, Nigeria.

$\mathrm{H}_{05}$ : Change in government policy does not significantly affect tax compliance among agroallied industries in Katsina state, Nigeria.

$\mathrm{H}_{06}$ : There is no significant effect of peer influence on tax compliance among agro-allied industries in Katsina state, Nigeria.

$\mathrm{H}_{07}$ : Simplicity of tax system has no significant effect on tax compliance among agro-allied industries in the selected local government areas in Katsina state.

$\mathrm{H}_{08}$ : Efficiency of tax authority does not significantly affect tax compliance among agroallied industries in the selected local government areas in Katsina state.

\section{Results and Discussions}

\subsection{Summary of Descriptive Statistics}

In order to obtain the data required to achieve the objectives of the study, 133 copies of questionnaires were distributed among the sample population in the study area and 108 copies were correctly filled and returned by the respondents. This depicts that the return rate is $81.2 \%$. The summary statistics of the variables are presented in table 1 . 
Table 1: Descriptive Statistics

\begin{tabular}{|c|c|c|c|c|c|c|c|c|c|c|}
\hline $\begin{array}{l}\text { Statistics } \\
\text { Criteria }\end{array}$ & $\mathbf{R}$ & I & $\mathbf{L}$ & P G S & $\mathbf{P}$ & C G P & $\mathbf{P}$ & S T S & E T A & $\mathbf{T}$ \\
\hline Observations & 108 & 1 & 0 & 108 & $\begin{array}{lll}1 & 0 & 8\end{array}$ & $\begin{array}{lll}1 & 0 & 8\end{array}$ & $\begin{array}{lll}11 & 0 & 8\end{array}$ & $\begin{array}{lll}1 & 0 & 8\end{array}$ & 108 & 108 \\
\hline$M \quad \mathrm{e} \quad \mathrm{n}$ & 1.76 & 1 & 66 & 2.03 & 1.11 & 1.19 & 1.45 & 1.21 & 1.08 & 1.63 \\
\hline Variance & .857 & & 576 & 1.224 & .268 & .339 & .549 & .393 & .208 & .291 \\
\hline Standard Deviation & .926 & & 322 & 1.106 & .518 & .582 & .741 & .627 & 456 & 540 \\
\hline S kewnes s & .501 & & 714 & 1.127 & .158 & 1.116 & .961 & .191 & .339 & 008 \\
\hline $\mathrm{Kurtosis}$ & 2.861 & 3 . & 145 & 2.710 & 2.920 & 2.881 & 3.217 & 3.062 & 2.702 & 2.933 \\
\hline Mini mu m & 1 & 1 & & 1 & 0 & 0 & 0 & 0 & 0 & 1 \\
\hline Maximum & 3 & 3 & & 5 & 2 & 3 & 2 & 2 & 2 & 3 \\
\hline
\end{tabular}

Source: Authors' Computation (2020).

Table 1 above presents the descriptive statistics of the primary data employed in the study. The essence is to ensure the quality of the data collected from the sample populationis used for analysis. As presented in the table, the selected variables used in the study include: Tax rate (TR), Income Level (IL), Perception on Government Spending (PGS), Perception on Equity (PE), Change in Government Policy (CGP), Peer Influence (PI), Simplicity of Tax System (STS), Efficiency of Tax Authority (ETA) and Tax Compliance (TC). In order to determine whether the series employed follow normal distribution two tests were considered which include: Skewness and Kurtosis statistics. The table revealed that all the series of the variables are positively skewed to the right. Also, the Kurtosis statistic shows that all the series were symmetric and normally distributed as each is approximately equal to three (which is the threshold).

Table 2 presents the demographic characteristics of the respondents in form of crosstab analysis adaptation. The results as shown in the table indicate that $50.9 \%$ of the agro-allied production firms in the study area are in fertilizer industry; while only $0.9 \%$ engage in textile production. The rice and maize flour mills represent $10.2 \%$ and $6.5 \%$ respectively. In terms of the years the industries took in operation, most of them (49) are between 3-5 years which represents $45.4 \%$. Very few of them were established since over 10 years (7.4\%). Also, most of the questionnaires were responded by either the M.D/Chairman/C.E.O or the secretary of each company $=32(29.6 \%)$ for each. Similarly, accountants and other officials represent only $1.9 \%$ respectively. Moreover, $24.1 \%$ represent industries with workers between 21-30; while 
$10.2 \%$ of the industries have employees between 100 and above. The industries with few workers $(1-10)$ captured $18.5 \%$. Furthermore, $78.7 \%$ of the industries registered with corporate affairs commission, and only $21.3 \%$ have not yet registered with the commission.

Table 2: Demographic Characteristics of the Respondents

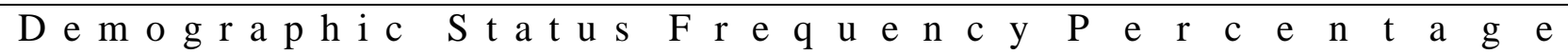
Main Business Activity

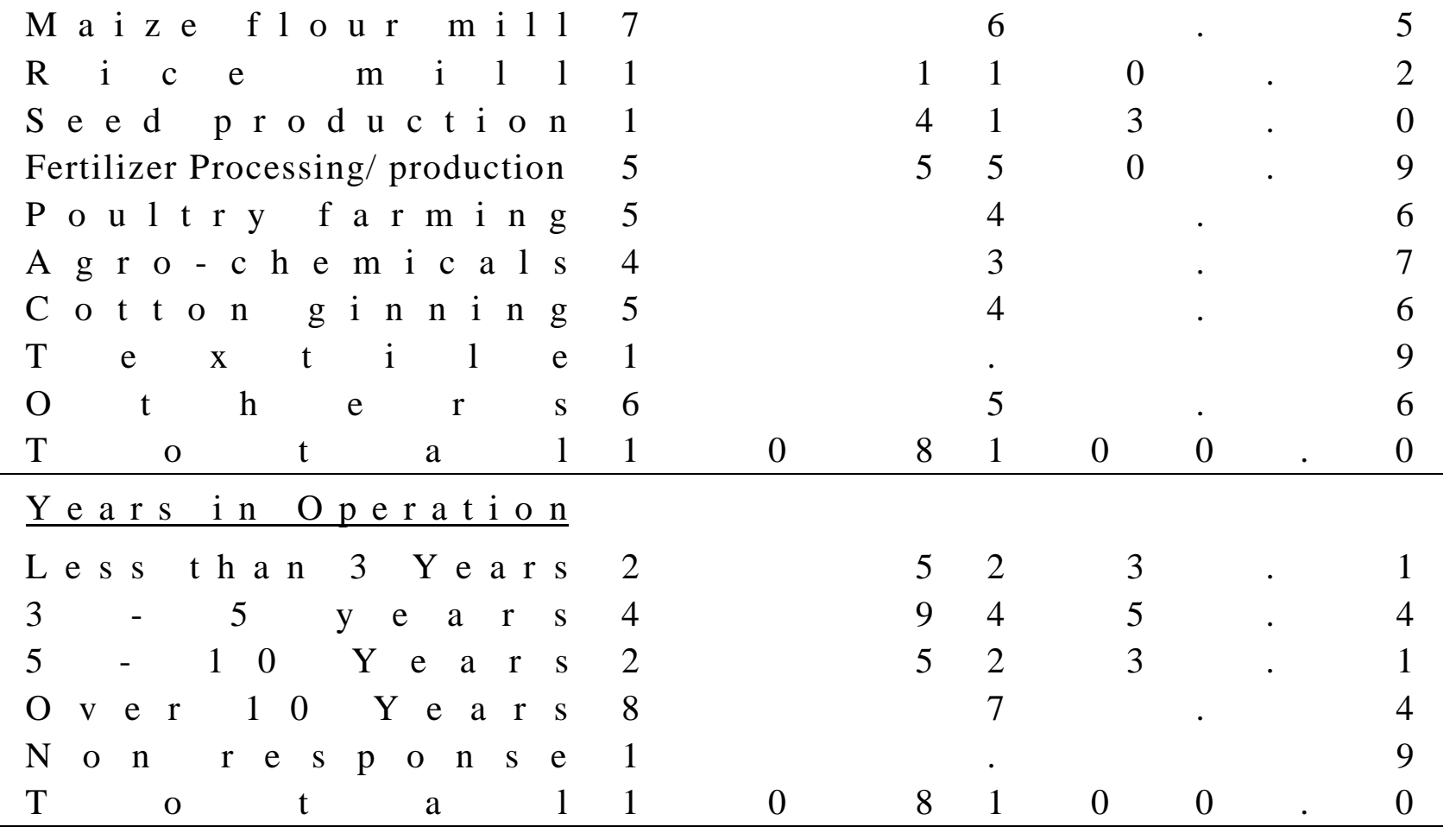

$\underline{\text { Rank of the Officer Responded }}$

M.D/Chairman/ C.E.O 3

$\begin{array}{lllll}2 & 2 & 9 & 6\end{array}$

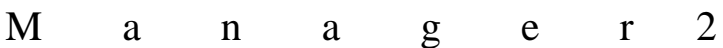

$\begin{array}{llllllllll}S & \text { e } & c & r & \text { e } & t & a & r & y & 3\end{array}$

$\begin{array}{lll}6 & 2 & 4\end{array}$

229

$\begin{array}{lllllllllll}A & c & c & o & u & n & t & a & n & t & 2\end{array}$

$\begin{array}{lllll}0 & 8 & 1 & 0 & 0\end{array}$

0

Number of Employees

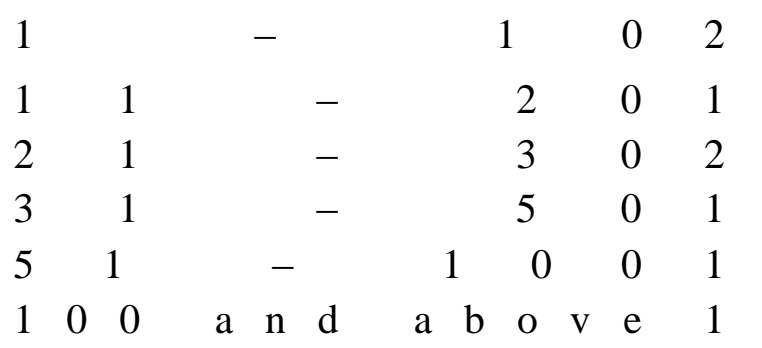




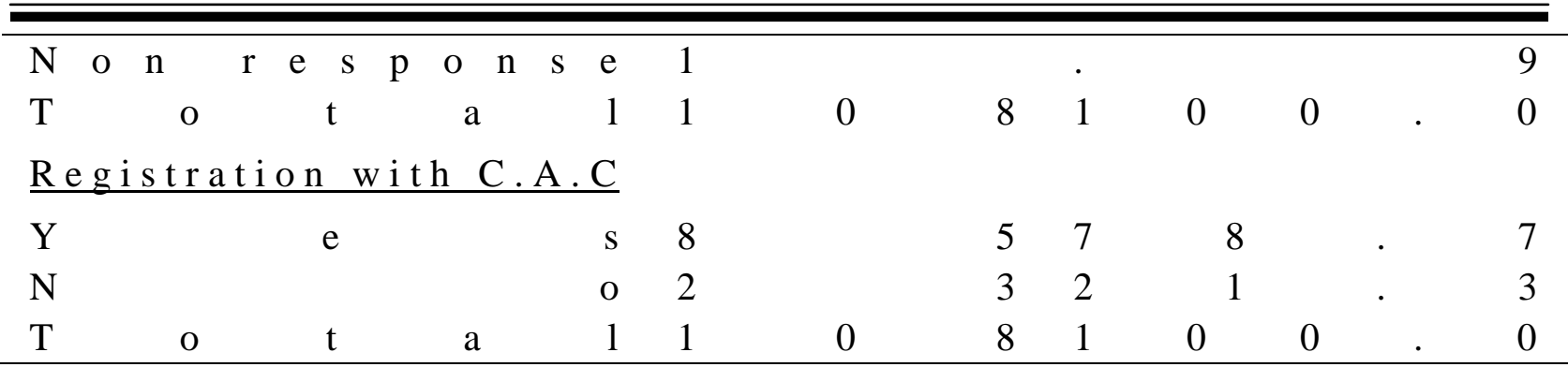

Source: Authors' Computation (2020).

\subsection{Results of Diagnostics Tests}

Table 3 shows that out of the total copies of 108 questionnaires filled and returned by the respondents, 43 copies $(39.8 \%)$ are in favor of tax compliance, while 62 out of the total responses are related to tax evasion, capturing 57.4\%. Only 3 are in favor of tax avoidance covering $2.8 \%$ of the total responses. The result further reveled that other forms of tax noncompliance have no room among the agro-allied industries in the study area as it has zero outcome. This depicts that $57.4 \%$ of the taxpayers evade tax, while $39.8 \%$ comply with tax laws, and only $2.8 \%$ avoid it.

Table 3: Case Processing Summary

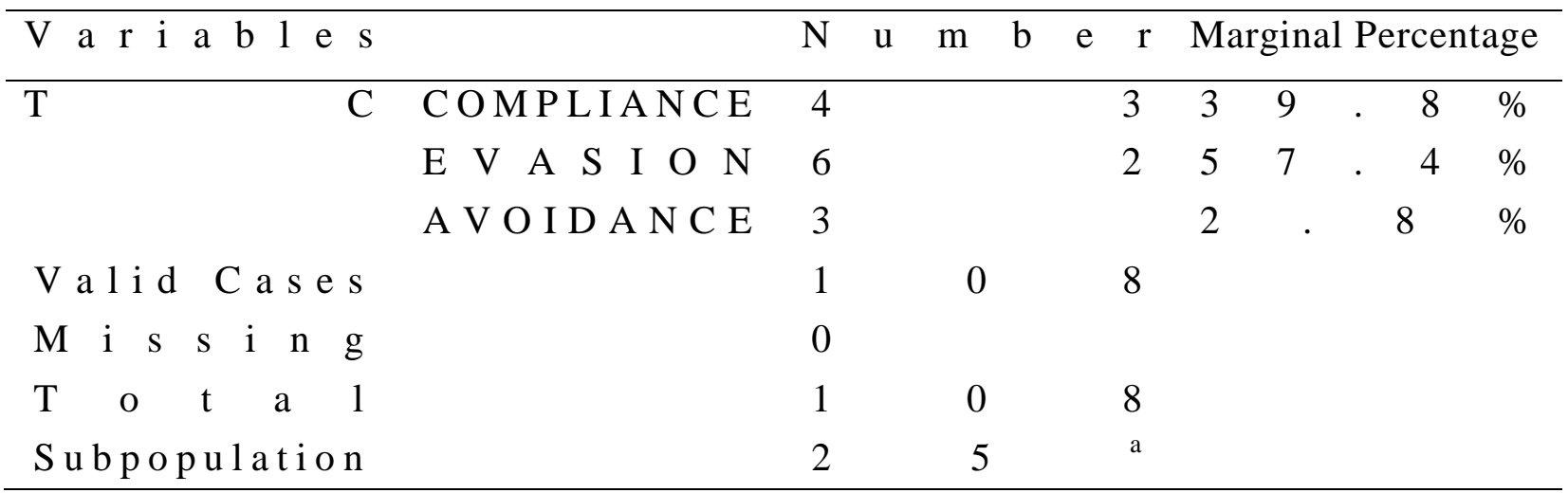

Source: Authors' Computation (2020).

In order to determine whether the independent variables incorporated in the model jointly fit the regression model, the study used chi-square as an assessment test. From table 4, the value of chi-square is 19.812 which is greater than the value of tabulated chi-square at $5 \%$ significance level (15.507). The evidence shows that the explanatory variables employed, can jointly affect the dependent variable. This implies that, economic, the social and institutional factors considered in the model are among the best set of the factors affecting tax compliance among agro-allied industries in the study area.

Table 4: Model Fitting Information

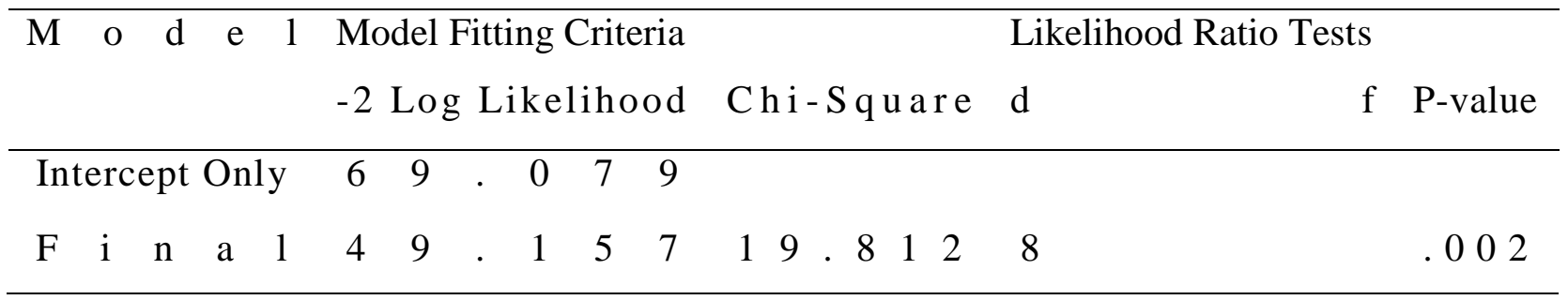




\section{Source: Authors' Computation (2020).}

Table 5 presents the results of pseudo R-square which represents the variation of the explanatory variables in relation to the dependent variables. The study considers the result of Nagelkerke and its value is 0.437 . This implies that $43.7 \%$ of the variation in the dependent variable can be accounted for by the explanatory variables, while other factors not considered by the study account for the remaining percentages.

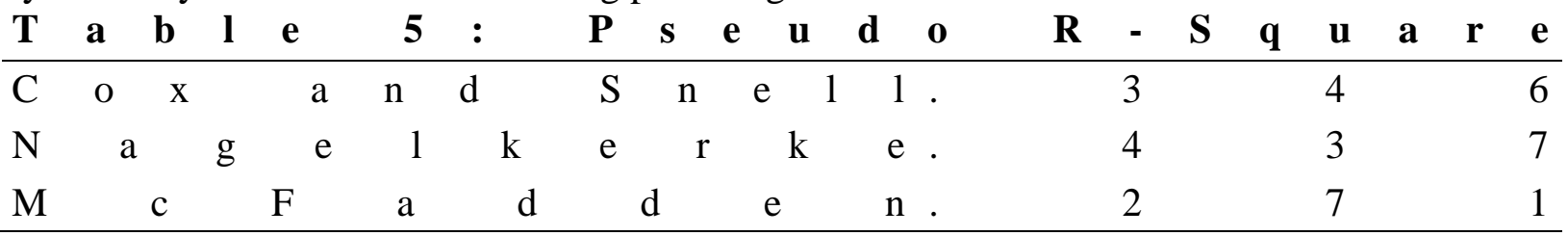

\section{Source: Authors' Computation (2020).}

In order to examine how the explanatory variables individually fit the model, the likelihood ratio test is considered. From table 6, the p-value of variable TR is 0.101 which is approximately equal to $10 \%$ level of significance, implying that tax rate has individually fit the model. The result also revealed that the p-value of variable IL is 0.000 . This means that income level also fit the regression line. Table 6 equally revealed that perception on government spending has fitted the model as its p-value is 0.035 (less than $5 \%$ significance level). As shown in the table, perception on equity does not fit the model because its p-value is greater than $10 \%$ significance level (0.941). Accordingly, CGP has p-value of 0.004 which is less than $5 \%$ level of significance. This signifies that change in government policy fits the regression line.

\section{Table 6: Likelihood Ratio Tests}

\begin{tabular}{llllll}
\hline E f f e c t & M o d e l Fit t i n g & C r i t e r i a & \multicolumn{2}{c}{ Likelihood Ratio Test } \\
& -2 Log Likelihood of Reduced Model & Chi-Square & D & f & S i g.
\end{tabular}

\begin{tabular}{|c|c|c|c|c|c|c|c|c|c|c|c|c|}
\hline \multicolumn{3}{|c|}{ Intercept } & 1 & 1 & 0 & 2 & 3 & 0 & $\mathrm{a}$ & 2.523 & 2 & .002 \\
\hline $\mathrm{T}$ & & $\mathrm{R}$ & 1 & 1 & 3 & & 7 & 7 & 1 & 6.064 & 2 & .101 \\
\hline I & & $\mathrm{L}$ & 1 & 2 & 1 & & 0 & 5 & 5 & 13.348 & 2 & .000 \\
\hline $\mathrm{P}$ & $\mathrm{G}$ & $\mathrm{S}$ & 1 & 1 & 4 & 2 & 7 & 9 & $\mathrm{a}$ & 6.572 & 2 & .037 \\
\hline $\mathrm{P}$ & & $\mathrm{E}$ & 1 & 0 & 7 & 8 & 2 & 9 & a & . 122 & 2 & .941 \\
\hline $\mathrm{C}$ & $\mathrm{G}$ & $\mathrm{P}$ & 1 & 1 & 8 & & 7 & 5 & 7 & 11.050 & 2 & .004 \\
\hline$P$ & & I & 1 & 0 & 8 & 4 & 1 & 9 & $\mathrm{a}$ & . $\begin{array}{lll}7 & 1 & 1\end{array}$ & 2 & .701 \\
\hline S & $\mathrm{T}$ & $\mathrm{S}$ & 1 & 1 & 1 & & 5 & 8 & 0 & 3.873 & 2 & .144 \\
\hline $\mathrm{E}$ & $\mathrm{T}$ & A & 1 & 1 & 0 & 4 & 5 & 8 & $\mathrm{a}$ & 2.751 & 2 & .253 \\
\hline
\end{tabular}

Source: Authors' Computation (2020).

As presented in table 6, the p-value of variable PI is 0.701 , which is greater than $10 \%$ level of significance. Hence, peer influence has not fitted the model. Furthermore, the results from the table also revealed that simplicity of tax system does not fit the regression line as its p-value is 0.144 (greater than $10 \%$ significance level). Lastly in this regard is the efficiency of tax authority which does not individually fit the model, because, its p-value is 0.253 , which is greater than $10 \%$ significance level. 


\subsection{Result of Multinomial Probit Regression}

The result of multinomial probit model is presented in table 7, which shows the coefficient of TR as -0.6675 , this implies that tax rate is negatively related with tax compliance. Accordingly, the coefficient of IL is -0.8586 showing that income level is also negatively related with tax compliance; the higher the level of income the lower the compliance. At the same vein, the coefficient of PGS (0.5210) suggests direct relationship between perception on government spending and tax compliance. Furthermore, the coefficient of PE is 0.1453 which also advocates positive relationship between perception on equity and tax compliance. Moreover, the result presents the coefficient of CGP as -0.6536 which reveals indirect relationship between change in government spending and tax compliance. Similarly, the relationship between peer influence and tax compliance is negative as the value of the coefficient of PI is -0.2213 . Also, the coefficient of variable STS is 0.6256 which shows that simplicity of tax system has positive relationship with tax compliance. Lastly in this regard is the coefficient of variable ETA (0.7257), which shows positive relationship between efficiency of tax authority and tax compliance.

Table 7: Result of Multinomial Probit Regression

\begin{tabular}{|c|c|c|c|c|c|c|c|c|c|c|}
\hline $\mathrm{C}$ & & & $\mathrm{a}$ & $\mathrm{C} \quad \mathrm{o} \quad \mathrm{e}$ & $\mathrm{f}$ & Std. & Err & & z-value & p-value \\
\hline Compliance & $\mathrm{T}$ & & $\mathrm{R}$ & -.667 & 5 & 3 & 2 & 4 & -2.08 & 0.073 \\
\hline & I & & $\mathrm{L}$ & -.858 & 6 & 3 & 5 & 9 & -2.23 & 0.026 \\
\hline & $\mathrm{P}$ & G & $\mathrm{S}$ & . $\begin{array}{lll}5 & 2 & 1\end{array}$ & 0 & 2 & 6 & 8 & 2.52 & 0.012 \\
\hline & $\mathrm{P}$ & & $\mathrm{E}$ & . 145 & 3 & 3 & 9 & 1 & 0.39 & 0.694 \\
\hline & $\mathrm{C}$ & G & $\mathrm{P}$ & -.653 & 6 & 3 & 5 & 9 & -1.99 & 0.039 \\
\hline & $\mathrm{P}$ & & I & -.221 & 3 & 2 & 7 & 1 & -0.83 & 0.407 \\
\hline & $\mathrm{S}$ & $\mathrm{T}$ & $\mathrm{S}$ & .625 & 6 & 3 & 6 & 5 & 1.98 & 0.048 \\
\hline & $\mathrm{E}$ & $\mathrm{T}$ & A & . 725 & 7 & 4 & 3 & 4 & 1.99 & 0.096 \\
\hline & - & $\mathrm{O}$ & & -1.663 & 0 & 1.0 & $\begin{array}{ll}5 & 1\end{array}$ & 9 & -1.58 & 0.114 \\
\hline
\end{tabular}

Source: Authors' Computation (2020).

\subsection{Discussion of Findings}

The result of this study shows the coefficient of TR as -0.6675 . This implies that a $1 \%$ increase in tax rate leads to 0.67 decrease in tax compliance. The variable is statistically significant because the p-value (0.073) is less than $10 \%$ significance level and the $\mathrm{z}$-value (2.08) is greater than the tabulated value at 5\% significance level (1.96). As such, hypothesis $\mathrm{H}_{01}$ is accepted. This implies that when tax authority rises tax, the agro-allied industries decrease the compliance behavior in order to compensate decrease in their real income. As such, a reduction in tax rate would lead to positive compliance that will result to more revenue generation. This finding is consistent with that of Park and Hyun, (2003) and Tanzi (1980) which found an inverse relationship between tax rate and tax compliance.

With regards to variable IL, the result shows that a $1 \%$ increase in the level of income leads to 0.86 decrease in tax compliance. The influence of IL on the dependent variable is statistically significant in that the p-value (0.026) is less than $5 \%$ significance level and the zvalue (2.23) is greater than the tabulated value at $5 \%$ level of significance (1.96). Hence, 
hypothesis $\mathrm{H}_{02}$ is accepted. The implication of this evidence is that the taxpayers in high income bracket in the agro-allied industry have low compliance behavior compared to low income earners. This may have connection with the fact that the tax paid by high income earners is in large amount which may serve as a discouraging factor for them to give out such huge amount to the government. This evidence is consistent with finding of Mohani (2001). Similarly the coefficient of PGS signifies that a $1 \%$ increase in perception on government spending leads to 0.52 increase in tax compliance. However, the relationship is statistically significant because the p-value is 0.012 which is less than $5 \%$ significance level and the zvalue is 2.52 which is greater than the tabulated value (1.96) at 5\% level of significance. Therefore, hypothesis $\mathrm{H}_{03}$ is rejected. This implies that when taxpayers in agro-allied industry perceive government spending as favorable they tend to increase the compliance behavior, and reverse is the case. Therefore, an efficient spending of public fund by the government serves as an indication that when citizens pay tax it would be used for the general wellbeing of the society which motivates the taxpayers to increase compliance behavior. This evidence is consistent with the fiscal exchange theory; and finding of Tilahun (2018).

Furthermore, the coefficient of PE signifies that a $1 \%$ increase in perception on equity leads to 0.15 increase in tax compliance. The result further reveals that the relationship between perception on equity and tax compliance is statistically insignificant because the p-value (0.694) is above $10 \%$ level of significance and the $\mathrm{z}$-value (0.39) is below the tabulated value at $5 \%$ significance level (1.96). As such, hypothesis $\mathrm{H}_{04}$ is rejected. This implies that perception on equity (being it vertical, horizontal or exchange equity) does not serve as a factor to be considered before complying with the tax law among the agro-allied industries in the study area. This evidence is consistent with the finding of Israel (1992). Accordingly, the result shows that a $1 \%$ increase in change in government policy leads to 0.65 decrease in tax compliance; and that the relationship between the two variables is statistically significant due to the fact that the p-value of variable CPG is 0.039 which is less than $5 \%$ significance level and that the $\mathrm{z}$-value is 1.99 which is greater than tabulated value at $5 \%$ level of significance (1.96). Hence, hypothesis $\mathrm{H}_{05}$ is accepted. This implies that a frequent change in government policy which does not have positive impact on the citizens leads to a decrease in compliance behavior among the taxpayers in the agro-allied industry in the study area. This finding is consistent with the evidence of Hasseldine and Hite (2003). In the same vein, the coefficient of PI signifies that a $1 \%$ increase in peer influence leads to 0.22 decrease in tax compliance. The p-value (0.407) and the $\mathrm{z}$-value (0.83) show that the relationship between peer influence and tax compliance is statistically insignificant. Therefore, hypothesis $\mathrm{H}_{06}$ is rejected. This implies that the decision of some taxpayers in the agro-allied industry in the study area never influence the decision of others. This evidence is inconsistent with that of Ajzen and Fishbein (1980).

Moreover, the result proves that a $1 \%$ increase in simplicity of the tax system leads to 0.63 increase in tax compliance. It is also shown that the relationship between the two variables is statistically significant as the p-value (0.048) is less than $5 \%$ significance level and the $\mathrm{z}$ value (1.98) is greater than tabulated value at 5\% level of significance (1.96). This allows the study to accept hypothesis $\mathrm{H}_{07}$. The implication of this evidence is that the more the tax authorities come-up with simpler, easier and convenient means of tax collection, the more the taxpayers comply with the tax laws as found by Amina and Saniya (2015). Lastly in this regard is the ETA in which its coefficient implies that a $1 \%$ increase in efficiency of the tax authority leads to 0.73 increase in tax compliance. While the p-value which is 0.096 and the 
z-value (1.99), which shows the existence of significant relationship between efficiency of tax authority and the tax compliance. This enables the study to accept hypothesis $\mathrm{H}_{08}$. The implication is that efficiency of tax authority in the form of efficient tax administration reduces the level of noncompliance and increase the compliance behavior among agro-allied industries in the selected local governments of Katsina state. This is consistent with the finding of Silvani and Baer (1997).

\section{Conclusion and Recommendations}

This study empirically examines the determinants of tax compliance; with focus on agroallied industries in Katsina state, Nigeria. The results of multinomial probit regression analysis presented in table 7, demonstrate that out of the eight (8) explanatory variables utilized in the model, six (6) of them are significant determinants of tax compliance, which are: tax rate, level of income, perception on government spending, change in government policy, simplicity of tax system and efficiency of tax authority. It is also evident that tax compliance is not significantly influenced by perception on equity and peer influence.In line with the findings of the study, the following recommendations are hereby presented:(i.) Government should efficiently execute capital projects preferred by citizens, this will satisfy the taxpayers that the tax collected by the government is for the general benefit of the society thereby increasing the level of compliance;(ii.) Tax authorities should provide easy and efficient means of tax payment and collection procedures, which shall go a long way in reducing the stress involved in tax payment; and(iii.) Accountability and transparency in tax payment and collection should be improved and corruption should be curtailed, which in many cases deteriorates revenue yields to the government. 


\section{References}

Abiola, J. \&Asiweh, M. (2012). Impact of tax administration on government revenue in a developing economy: Case study of Nigeria. International Journal of Business and Social Science, 3(8), 99-113.

Ajaz, T. \& Ahmad, E. (2010). The effect of corruption and governance on tax revenue.Pakistan Development Review, 49(4), 405-417.

Ajzen, I. and Fishbein, M. (1980).Understanding attitudes and predicting social behavior. Englewood Cliffs, New Jersey: Prentice Hall.

Akintoye, I.R. \& Dada, S.O. (2013). Tax justice, economic growth and development in subSaharan Africa: Evidence from Nigeria. Journal of Management Policy, 3(5), 104120.

Akinyomi, O.J. \&Okpola, K. (2013).Appraisal of factors influencing tax avoidance and evasion in Nigeria.International Journal of Research in Commerce and Management, 4(5), 107-111.

Alabede, O.J., Ariffin Z.A. \&Idris, K.M. (2011). Determinants of tax compliance behavior: A proposed model for Nigeria. International Research Journal of Finance and Economics, 5(78), 122-136.

Aladejebi, O. (2018). Measuring tax compliance among small and medium enterprises (SMEs) in Nigeria. International Journal of Accounting and Taxation, 6(2), 29-40.

Ali, M., Fjeldstad, O. \&Sjursen, I.H. (2014).Factors affecting tax compliance attitude in africa: Evidence from Kenya, Tanzania, Uganda and South Africa. Bergen. Norway: Chr. Michelson Institute Bergen.

Allingham, M. \&Sandmo, A. (1972). Income tax evasion: A theoretical analysis. Journal of Public Economics, 1(3-4), 323-338.

Alm, J. \& Martinez-Vazquez, J. (2001).Societal institutions and tax evasion in developing and transitional countries. A Working Paper for Public Finance in Developing and Transition Countries: A Conference in Honor of Richard Bird International Studies Program, Andrew Young School of Policy Studies, Georgia State University.

Alm, J. (1995).A perspective on the experimental analysis of taxpayer reporting.The Accounting Review, 66(3), 577-593.

Alm, J., McClelland, G.H.\&Schulze W.D. (1992). Why do people pay taxes? Journal of Public Economics, 48(1), 21-38.

Amina, A. \&Saniya K. (2015). Tax compliance and its determinant: Case of Jimma zone. International Journal of Research in Social Science, 6(2), 7-21.

Anyaduba, J.O., Eragbhe, E. \& Kennedy, P.M. (2012).Deterrent tax measures and tax compliance in Nigeria.Journal of Business and Management, 4(11), 37-44. 
Assfawa, A.M. \&Sebhat, W. (2019). Analysis of tax compliance and its determinants: Evidence from Kaffa, Bench Maji and Sheka zones category B tax payers, SNNPR, Ethiopia. Journal of Accounting, Finance and Auditing Studies, 5(1), 32-58.

Azubike, J.B.U. (2009). Challenges of tax authorities, taxpayers in the management of tax reform processes. The Nigerian Accountant, 42(2), 36-42.

Banerjee, A.V. (1992). A simple model of herd behavior.The Quarterly Journal of Economics, 107(1), 797- 817.

Cowell, F.A. \&Gordon, J.P.F. (1988). Unwillingness to pay: Tax evasion and public good provision. Journal of Public Economics,36(1), 305- 321.

D'Arcy, M. (2011). Why do citizens assent to pay tax? Legitimacy, taxation and the African state.Afrobarometer Working Paper No. 126.

Deyganto, K.A. (2008). Factors influencing taxpayers' voluntary compliance attitude with tax system: Evidence from Gedeo zone of Southern Ethiopia. Universal Journal of Accounting and Finance, 6(3), 92-107.

Dubbin, J.A. (2004).Criminal investigation enforcement activities and taxpayer noncompliance. Paper Presented at 2004 IRS Research Conference, Washington.

Economic Recovery and Growth Plan.(2017). Ministry of budget and national planning.https://www.yourbudget.com>economic_recovery_and_growth_plan

Eluro, D.C. (2018). Determinants of tax compliance under the self-assessment system in private secondary schools: Evidence from Delta North Senatorial Zone. Research Journal of Finance and Accounting, 9 (7), 95-108.

Fagbemi, T.O. \&Abogun, R. (2015).Factors influencing voluntary tax compliance of small and medium scale enterprises in Kwara State, Nigeria.Retrieved from www.ibrarian.net.

Fagbemi, T.O., Uadiale, O.M. \& Noah, A.O. (2010). Ethics of tax evasion: Perspective from Nigeria. European Journal of Social Sciences, 17(3), 23-38.

Fischer C.M., Wartick M. \& Mark M. (1992). Detection Probability and taxpayer Compliance: A Review of literature. Journal of Accounting Literature, 11(1), 1-46.

Fjeldstad, O.H. \&Semboja, J. (2001). Why people pay taxes: The case of the development levy in Tanzania. World Development, 29(1), 2059- 2074.

Franzoni, L.A. (1999). Tax evasion and tax avoidance.Enclopedia of Law and Economics. Italy: University of Bologna.

Hasseldine, J. \&Hite, P. (2003).Framing, gender and tax compliance.Journal of Economic Psychology, 24(4), 517-533.

HM Treasury, Revenue and Custom, (2019).National audit office.London, Buckingham Palace Road Victoria, United Kingdom.www.gov.uk/official-documents. 
Israel, G. (1992). Sampling the evidence of extension program impact, program evaluation and organizational development.Institution of Food and Agricultural Science, 2(1), $22-33$.

Jackson, B.R. \&Milliron, V.C. (1986). Tax compliance research: Findings, problems, and prospects. Journal of Accounting Literature, 5(1), 125-165.

James, S. \& Alley, C. (2002).Tax compliance, self-assessment and tax administration.Journal of Finance and Management in Public Services, 2(2), 27-42.

Kabel, B.D. \&Nwokah, G.N. (2009).Curbing tax evasion and avoidance in personal income tax administration: A study of south-south states of Nigeria, European Journal of Economic, Finance and Administrative Sciences, 15(2), 60-61.

Kirchler, E. (2007). The economic psychology of tax behavior. Cambridge: Cambridge University Press.

Kothari, C.R. (2004). Research methodology, methods and technique. New Delhi: New Age International Ltd., Publishers.

Ladi, O.M. \& Henry, I.T. (2015). Effects of tax audit on revenue generation: Federal Inland Revenue Service. Journal of Good Governance on Sustainable Development in Africa, 2(4), 67 -80.

Levi,M.(1988).Ofruleandrevenue.Berkeley:UniversityofCaliforniaPress.

Loo, E.C. (2006).The influence of the introduction on self-assessment on compliance behavior of individual taxpayers in Malaysia.PhD Thesis.University of Sydney.

Manaye M.K. (2018). Determinants of taxpayers' voluntary compliance with taxation: The case of WolaitaSodo and Tercha town in Dawuro zone. Global Journal of Management and Business Research, 18(3) 24-41.

Martini, M. (2014).Approaches to curving corruption in tax administration in Africa. Berlin. U4 Ant-corruption Resource Centre. Retrivede from https://www.transparency.org/whatwedo/answer/approaches_to_curving_corruption_i n_tax_administration_in_africa, 2020-01-20.

Mohani, A. (2001). Personal income tax non-compliance in Malaysia.PhD Thesis.Victoria University, Melbourne, Australia.

Moore, M. (2004).Revenues, state formation, and the quality of governance in developing countries.International Political Science Review, 25(1), 297-319.

Neill, J.R. (1999). The benefit and sacrifice of principles of taxation: A synthesis. Social Choice and Welfare, 17(1), 117-124. Retrieved from http://www.jstor.org/stable/41106343, 2019-12-22.

Ojo, S. (2003).Principles of Nigerian taxation. Lagos: Sagriba Tax Publications. 
Ojochogwu W.A. \& Stephen, O.A. (2012). Factors that affect tax compliance among small and medium enterprises (SMEs) in north-central Nigeria. International Journal of Business and Management, 7 (12), 78-96.

Okafor, R.G. (2012). Tax revenue generation and Nigerian economic development.European Journal of Business and Management, 4(19), 49-56.

Okpe, I.I. (2000). Personal income tax in Nigeria. Enugu: Ochumba Printing and Publishing Company.

Ola, C.S. (2001). Income tax law and practice in Nigeria(5th Edition). Ibadan: Dalag Prints and Part.

Oladele, R., Aribaba, F.O., Ahmodu, A.O., Yusuff, S.A. \&Alade, M. (2019). Tax enforcement tools and tax compliance in Ondo State, Nigeria. Academic Journal of Interdisciplinary Studies, 8(2), 27-38.

Olaoye, C.O., Ashaolu, T.O. \&Adewoye, J.O. (2009). A review of revenue generation in Nigerian local government: A case study of Ekiti State. International Business Management, 3(3), 54-60.

Oyedele, T. (2016). Guess how many Nigerians pay tax and how our government spends the money. Retrieved from http:// www.pwenigeria.typepad.com, 2019-12-13.

Palil, M.R.(2010). Tax knowledge and tax compliance determinants in self-assessment system in Malaysia. A Thesis Submitted to The University of Birmingham for the Degree of Doctor of Philosophy. Birmingham: The University of Birmingham.

Park, C., and Hyun, J.K.(2003). Examining the determinants of tax compliance by experimental data: A case of Korea.Journal of Policy Modelling, 25(8), 673-684.

Riahi-Belkaoui, A. (2004). Relationship between tax compliance internationally and selected determinants of tax morale. Journal of International Accounting, Auditing and Taxation, 13(2), 135-143.

Richardson, G. (2008). The relationship between culture and tax evasion across countries: Additional evidence and extensions. Journal of International Accounting, Auditing and Taxation, 17(2), 67-78.

Richupan, S. (1987). Determinants of income tax evasion: Role of tax rates, shape of tax schedules and other factors. Gandhi, V.P. (ed.). International Monetary Fund.

Roth, J.A. Scholz, J.T. \& Dry-Witte, J.T. (1989).Taxpayer compliance.An agenda for research. Philadelphia: University of Pennsylvania Press.

Silvani, C. \& Baer, K. (1997).Designing a tax administration reform strategy: Experiences and guidelines.International Monetary Fund.

Snavely, K. (1990). Governmental policies to reduce tax evasion: coerced behavior versus services and values development. Policy Sciences, 23(1), 57-72. 
Soos, P. (1991). Self-employed evasion and tax withholding: A comparative study and analysis of the issues. Working paper, University of California.

Soyode, L. \&Kayola, S.O. (2006).Taxation: Principles and practice in Nigeria (1st Edition). Ibadan: Silicon Publishers.

Sparc Report (2014). Report on Katsina state internally generated revenue improvement strategy. www.sparc-nigeria.com>files.

Tanzi, V. (1980).Inflationary expectations, economic activity, taxes, and interest rates.The American Economic Review, 70(1), 12-21.

Tilahun, M. (2018). Economic and social factors of voluntary tax compliance: Evidence from Bahirdar city. International Journal of Account, 6(2), 182-189.

Tilly, C. (1992). Coercion, capital and European states: AD 990-1992. Malden, Massachusetts: Blackwell Publishers Inc.

Torgler, B. (2007). Tax compliance and tax morale: A theoretical and empirical analysis. Journal of Economic Surveys, 16(5), 27-40.

Transparency International, (2016).FAQs on corruption.Retrieved from http://www.transparency.org/whoweare/organisation/faqs, 2019-12-22.

Wärneryd, K.E. \&Walerud, B. (1982). Taxes and economic behavior: Some interview data on tax evasion in Sweden. Journal of Economic Psychology, 2(3), 187-211.

Whitte, A. \& Woodbury, D. (1985). The effect of tax laws and tax administration on tax compliance: The case of the U.S. individual income tax. National Tax Journal, 38(1), $1-13$.

Yenkelovic, K. \&Whita (1984). Taxpayers' attitudes study: Final report. Public opinion survey prepared for the Internal Revenue Services. Washington, DC: Internal Revenue Service, U.S. Department of the Treasury. 